\title{
Quantitative susceptibility mapping suggests a paramagnetic effect in PML
}

Figure 1 Brain MRI fluid-attenuated inversion recovery and T2* images
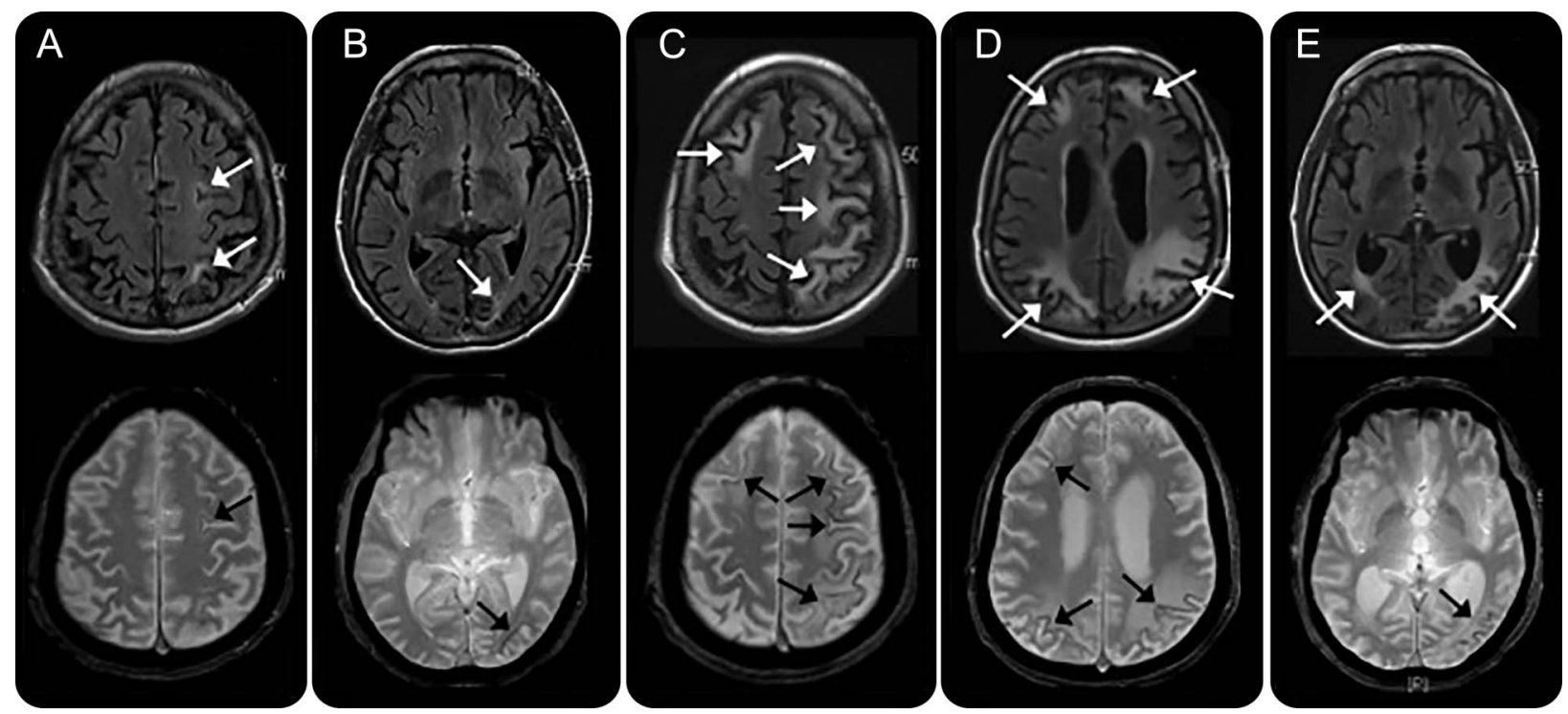

Initial MRI revealed hyperintensities of the subcortical white matter on fluid-attenuated inversion recovery and adjacent cortical hypointensities on T2* (A, B). One year later, abnormalities were more extensive (C-E).

A 42-year-old man previously treated with rituximab and stem cell transplantation for B-cell lymphoma presented with subacute cerebellar ataxia and cognitive decline.

Brain MRI revealed fluid-attenuated inversion recovery cortico-subcortical hyperintensities (figure 1, A and B). Adjacent cortex was hypointense on T2* (figure 1, A and B) and susceptibility-weighted imaging (SWI),

\section{Figure 2 Brain MRI}
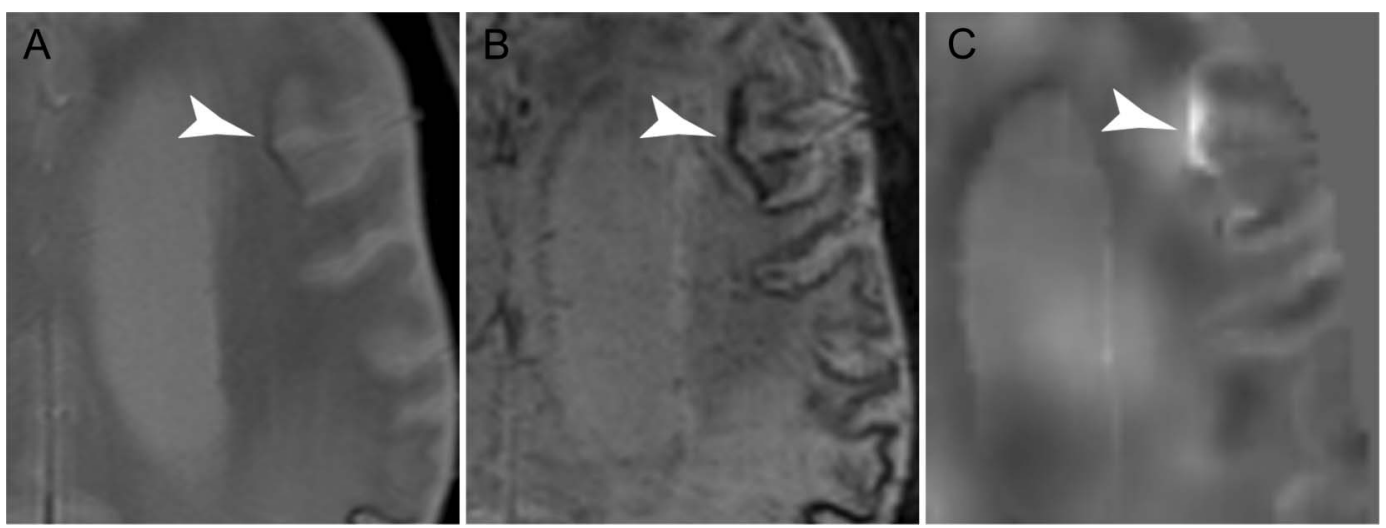

White arrowhead: cortical paramagnetic effect, hypointense on $\mathrm{T}^{*}(\mathrm{~A})$ and susceptibility-weighted imaging (B), hyperintense on quantitative susceptibility mapping (C). 
hyperintense on quantitative susceptibility mapping (QSM) (figure 2). CSF PCR analysis showed JC virus DNA. Follow-up MRI revealed more extensive lesions (figure 1, C-E).

SWI hypointensities have been described recently in progressive multifocal leukoencephalopathy (PML) ${ }^{1}$ suggesting diamagnetic (calcifications) or paramagnetic (blood degradation products or non-heme iron deposits) effect. ${ }^{2}$ This report using QSM in PML strongly suggests a paramagnetic effect.

Clarisse Carra-Dalliere, MD, Nicolas Menjot de Champfleur, MD, PhD, Xavier Ayrignac, MD, Jeremy Deverdun, Pierre Labauge, $M D, P h D$

From Gui de Chauliac Hospital (C.C.-D., N.M.d.C., X.A., J.D., P.L.), Montpellier University Hospital Center; Institut of Neurosciences of Montpellier (N.M.d.C.); and Montpellier II University (J.D.), France.

Author contributions: C. Carra-Dalliere, X. Ayrignac, and P. Labauge participated in drafting/revising the manuscript. N. Menjot de Champfleur participated in analysis of the data and revising the manuscript. J. Deverdun participated in analysis of the data. Study Funding: No targeted funding reported.

Disclosure: The authors report no disclosures relevant to the manuscript. Go to Neurology.org for full disclosures.

Correspondence to Dr. Carra-Dalliere: clarisse.carra@gmail.com

1. Miyagawa M, Maeda M, Umino M, et al. Low signal intensity in U-fiber identified by susceptibility-weighted imaging in two cases of progressive multifocal leukoencephalopathy. J Neurol Sci 2014;344:198-202.

2. Wang Y, Liu T. Quantitative susceptibility mapping (QSM): decoding MRI data for a tissue magnetic biomarker. Magn Reson Med Epub 2014 July 7. 


\section{Neurology}

Quantitative susceptibility mapping suggests a paramagnetic effect in PML Clarisse Carra-Dalliere, Nicolas Menjot de Champfleur, Xavier Ayrignac, et al. Neurology 2015;84;1501-1502

DOI 10.1212/WNL.0000000000001455

\section{This information is current as of April 6, 2015}

\section{Updated Information \& Services}

\section{References}

Citations

Subspecialty Collections

Permissions \& Licensing

\section{Reprints}

including high resolution figures, can be found at: http://n.neurology.org/content/84/14/1501.full

This article cites 1 articles, 0 of which you can access for free at: http://n.neurology.org/content/84/14/1501.full\#ref-list-1

This article has been cited by 4 HighWire-hosted articles: http://n.neurology.org/content/84/14/1501.full\#\#otherarticles

This article, along with others on similar topics, appears in the following collection(s):

\section{MRI}

http://n.neurology.org/cgi/collection/mri

Information about reproducing this article in parts (figures,tables) or in its entirety can be found online at:

http://www.neurology.org/about/about_the_journal\#permissions

Information about ordering reprints can be found online:

http://n.neurology.org/subscribers/advertise

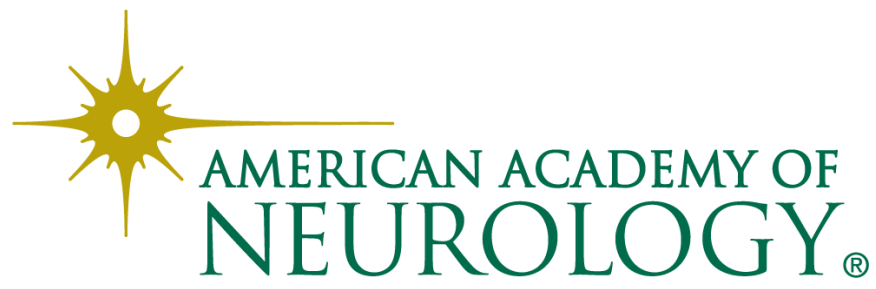

